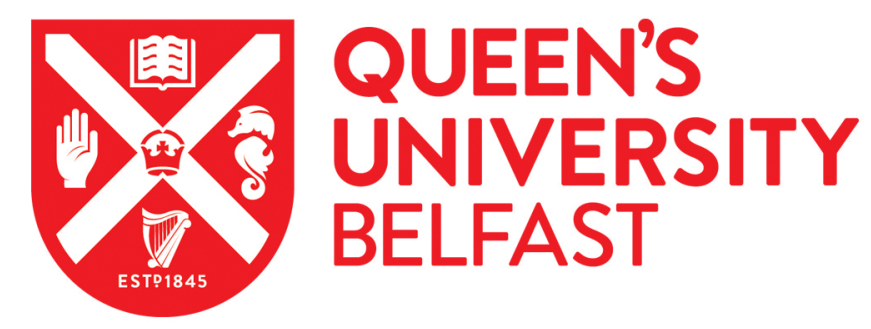

\title{
The role of blended contact for community cohesion: Lessons from Northern Ireland
}

Austin, R., \& Turner, R. N. (2020). The role of blended contact for community cohesion: Lessons from Northern Ireland. Technology Pedagogy and Education. https://doi.org/10.1080/1475939X.2020.1756906

Published in:
Technology Pedagogy and Education

Document Version:

Peer reviewed version

Queen's University Belfast - Research Portal:

Link to publication record in Queen's University Belfast Research Portal

Publisher rights

(c) 2020 Association for Information Technology in Teacher Education.

This work is made available online in accordance with the publisher's policies. Please refer to any applicable terms of use of the publisher.

\section{General rights}

Copyright for the publications made accessible via the Queen's University Belfast Research Portal is retained by the author(s) and / or other copyright owners and it is a condition of accessing these publications that users recognise and abide by the legal requirements associated with these rights.

Take down policy

The Research Portal is Queen's institutional repository that provides access to Queen's research output. Every effort has been made to ensure that content in the Research Portal does not infringe any person's rights, or applicable UK laws. If you discover content in the Research Portal that you believe breaches copyright or violates any law, please contact openaccess@qub.ac.uk. 


\title{
The role of blended learning for community cohesion: Lessons from Northern Ireland
}

\author{
Roger Austin; rsp.austin@ulster.ac.uk*; corresponding author \\ Ulster University, Cromore Road, Northern Ireland, BT52 1SA \\ Rhiannon N.Turner;r.turner@qub.ac.uk \\ Queen's University Belfast, University Road, Belfast, Northern Ireland BT7 1NN
}

\begin{abstract}
The rise of populist nationalist politics round the world, endemic tensions around issues of identity and the displacement of millions of people through war and civil conflict has brought a sharp focus on the role that schools might play in building community cohesion.

This article presents the findings of survey data collected from 58 teachers (36 Catholic, 21 Protestant, 1 no affiliation) in Northern Ireland who had completed a course on 'blended learning', a blend of face to face and online contact, to link schools involved in Shared Education. This is the 2016 Northern Ireland government policy designed to bring pupils from different types of schools together to engage in purposeful curricular work and through collaborative learning, improve educational outcomes and learn respect for cultural difference. Although blended learning has the potential to increase the effectiveness of Shared Education, to date no research has empirically examined teachers' perceptions of what influence it has in this context. This study remedies that deficit. A number of important findings emerged from the research. First, prior to 2017, when teachers received training in blended learning, nearly all contact between their schools was face to face. After the training, teachers stated that the use of a Virtual Learning Environment (VLE) for joint work was used more than either real-time video-conferencing or face to face contact and was believed to have had the greatest impact on pupils' knowledge and attitudes towards each other. Two thirds of the teachers agreed that in their future planning for Shared Education, equal importance should be given to the place of online learning and face to face contact. Second, teachers reported that this approach had had a positive impact on friendship development, the capacity of children to work together, respect for difference and normalising relations between their pupils. Third, we suggest that this data provides strong endorsement of the use of blended learning for mainstreaming Shared Education in Northern Ireland and has important lessons in other parts of the world where issues of ethnicity, identity and faith are obstacles to community cohesion.
\end{abstract}

Keywords; blended learning; computer-mediated communication; collaborative learning; crosscultural projects; country-specific developments; improving classroom teaching

\section{Introduction}

Research on links between schools has increasingly included the role of ICT in connecting schools as part of a blended approach to community cohesion, where pupils are linked through both face to face work and regular online interaction. Turner \& Cameron (2016) underlined the potential value of 
this in providing a means for young people to have much more frequent contact than would be possible through face to face work, whilst Harwood, Hewstone, Amichai-Hamburger \& Tausch (2016) noted that online contact can overcome three of the challenges of face-to-face contact, namely practicality, anxiety and sustainability. Austin, Reilly \& Ricard (2017) demonstrated that ICT can supplement face to face work, notably by providing longer term engagement between pupils than would be otherwise be possible and offering teachers a model which is better able to fit into the demands of a busy teaching day. There is also evidence for the long-term benefits of intergroup contact through ICT in the classroom: Christian and Muslim students in Australia who took part in an online group classroom project showed reduced levels of prejudice and intergroup anxiety that remained six months after completion of the project (White \& Abu-Rayya, 2012, see also White et al., 2018). However, to date, there has been no empirical examination of the impact of blended learning in Northern Ireland.

Although $45 \%$ of the population in Northern Ireland is Catholic and 48\% Protestant (NISRA, 2011), 93\% of children attend schools that are predominantly Catholic or Protestant in ethos. Only $7 \%$ of children attend integrated schools where children of all faiths and none are educated together. Colleges of Further Education which provide vocational courses for 16-18 year-olds and Northern Ireland's two Universities are all 'mixed' in terms of their intake though it cannot be assumed that this means that Catholic and Protestant students necessarily mix comfortably. (Austin and Hunter 2013). Some research suggests that encountering difference and diversity is more likely to occur in the workplace than the neighborhood or in social settings (Eyben, Morrow, Wilson and Robinson 2002). There have been other countries with similar denominational schooling structures, like the Canadian province of Newfoundland, but when politicians there called a referendum in 1995 to ask if its citizens wished to end this arrangement, it was not because of fears that this system may produce sectarian attitudes but simply that the system was expensive and was not giving children enough curriculum choice (Galway \& Dibbon, 2012). What makes Northern Ireland's case more problematic is overlap between schooling choices and wider cultural and political perspectives. Put simply, children who attend schools with a Catholic ethos are more likely to come from families that cherish Irish culture and may support the aspiration for closer ties between Northern Ireland and the Republic of Ireland. In contrast, there is a much higher probability that children who attend schools with a Protestant ethos will belong to families who value British culture and identity. Moreover, these cultural and political preferences are expressed in housing patterns, in different sports and through political parties (Austin \& Anderson, 2008). Unlike the rest of the UK, the main political parties in Northern Ireland are broadly either in favour of close ties with the rest of Ireland, or in favour of retaining the existing ties within the United Kingdom.

This context is a legacy of 'the Troubles' where between 1968-1998, differences erupted into armed conflict between the Irish Republican Army (IRA) that wanted to force the British government to give up its hold on Northern Ireland, and the British army which was used by the British government to resist this. Loyalist paramilitary organisations, notably the Ulster Volunteer Force (UVF) and the Ulster Defence Association (UDA), joined the conflict ostensibly to protect the Protestant population's right to remain 'British'; in practice they often used the same approach as the IRA in targeting and killing civilians who were identified as belonging to the other side. In 1998, the Belfast Agreement, also known as the Good Friday Agreement, brought the armed conflict to an end (Taylor, 2006; Muldoon, Trew, Todd, Rougier \& McLaughlin 2007). Although there was considerable optimism at the time about what the agreement could deliver, it did not 'solve' the fundamental 
cause of conflict, the constitutional position of Northern Ireland. It remains the case today that nationalists and republicans would still seek to create a 'united' Ireland to include Northern Ireland while loyalists and Unionists want Northern Ireland to remain part of the United Kingdom.

So what has been the impact of the Belfast Agreement between 1998 and 2018? A recent research report to the United States Congress (Archik, 2018) noted that although the security situation had improved, challenges remain in achieving peace and reconciliation. It pointed out, for example, that 'Northern Ireland remains a largely divided society, with Protestant and Catholic communities existing in parallel', attending separate schools and living in separate housing estates (p. 1). Moreover, in the 12 months from December 2016 to December 2017, there were 852 sectarian incidents and 584 sectarian crimes (PSNI, 2018). Although, there is no political will to address these concerns via the abolition of the separate school system, politicians and civil servants have instead made changes to the curriculum, for example introducing face-to-face cross-community contact schemes, blended learning, and since 2008, through Shared Education.

In this paper we review the different programmes used to promote cross-community relations in schools, including previous work on blended learning, before proposing three key research questions which build on previous findings. Specifically, we will demonstrate that there is a gap in the literature regarding understanding the impact of blended learning as a component of Shared Education. We then present findings from a survey undertaken with teachers involved in teaching Shared Education classes following training to incorporate blended learning into the curriculum.

\subsection{Changing the curriculum}

Northern Ireland adopted a common curriculum for schools in 1989, meaning, for example, that all children studied the same periods of history including Irish, British and European topics. However, in examining citizenship education in Northern Ireland, O'Connor, Beattie, \& Niens (2008), noted that regardless of the intrinsic merits of the course content, the fact that pupils studied only with peers from the same community as themselves was a limitation in the learning environment. Indeed, Niens, Kerr \& Connolly (2013) reported that while a shared curriculum promoted more positive attitudes around cross-community relations, there was considerable added value for both the pupils and teachers when cross-community contact was part of joint study of the curriculum. Research on the contact hypothesis bolsters this argument.

\subsection{Face to face contact}

The contact hypothesis (Allport, 1954) is the premise that positive interactions between members of different social groups can improve intergroup relations, and is arguably the most intensively studied and applied theory of prejudice-reduction. In a recent review of intergroup contact research among young people, Turner \& Cameron (2016) highlighted considerable potential benefits of contact as well as challenges. On the one hand, contact is effective at promoting more positive intergroup attitudes, trust, and prosocial behavioural intentions, and reduced intergroup anxiety (e.g., Abbott \& Cameron, 2014; Pettigrew \& Tropp, 2006; Turner, Hewstone, \& Voci, 2007). On the other hand, children in settings characterised by diversity may experience poorer psychological adjustment, wellbeing and academic success, particularly when from a disadvantaged group (e.g., Brown et al., 2013). Turner and Cameron concluded that 'the key to resolving this dilemma may lie in the development of cross-group friendships. In diverse settings children have the opportunity to form 
meaningful relationships with people from backgrounds different to their own' (p. 213). Where such friendships develop, positive outcomes are more likely.

Face-to-face contact programmes have been introduced in Northern Ireland, but results here and elsewhere have been mixed. While Trew (1989) and O'Connor, Hartop \& McCully (2002) were relatively negative about face-to-face contact schemes, Abrams (2010) argued that both intergroup contact and school diversity tend to be associated with better intergroup understanding and more positive attitudes. Yet, Kerr et al (2011) found that even well planned meetings with relatively little travel did not necessarily change preconceived negative reactions from one group to another. They added an important rider to this view, namely the 'need for good quality pre-linking activities to try to break down existing stereotypes' (p. 57). In line with this argument, Turner and colleagues have demonstrated that pre-contact activities such as learning about other people's positive intergroup contact experiences (West \& Turner, 2014) or mental preparation by running through a script of what positive contact might look like (West, Turner, \& Levita, 2015) can enhance the success of intergroup contact.

\subsection{Blended learning}

From 1986-2016, two separate government funded projects in the United Kingdom and Ireland made extensive use of ICT to extend face to face contact between pupils. The European Studies (Ireland and Great Britain) project which ran from 1986-2016 linked schools in Northern Ireland with others in Ireland, the United Kingdom and mainland Europe (Austin \& Hunter, 2013). Following the Belfast Agreement of 1998, the locally elected administration in Northern Ireland and its counterpart in Ireland set up the Dissolving Boundaries Programme which was funded from 1999-2016 and involved 50,000 young people. Evidence has emerged from evaluation of these projects that this blended approach was welcomed by teachers and had an impact on the skills and attitudes of young people. Even a year after the contact came to an end pupils displayed more tolerance than matched pupils who had not been involved (Rickard \& Austin, 2017). In the design of this work, the combination of the contact hypothesis (Allport, 1954) and the reach of the internet were found to be critical (Austin \& Hunter, 2013; Hasler \& Amichai-Hamburger, 2013). Their findings corroborated external inspection of the programme (Education and Training Inspectorate, 2012) and external evaluation (Bonnell et al, 2010). Key conclusions showed that pupils gained better understanding of each other and developed enhanced ICT skills. Teachers also gained extensive professional development through having to use ICT to plan joint work with teachers in another jurisdiction. However, when external funding for this programme stopped in 2016, links between schools gradually withered.

\subsection{The ICT infrastructure in Northern Ireland}

In the context of Northern Ireland, the investment in the ICT infrastructure through a public-private partnership called C2K, first introduced in 1997, has brought the capacity of online contact within the reach of every child in every school ( Austin and Anderson 2008); in other words, ICT provision opens up the potential for an approach that would include all children irrespective of the type of school they attend. Furthermore, as part of the overall drive to encourage teachers to use ICT, the Department of Education in Northern Ireland has been steadily increasing its expectations that the use of ICT should be either accredited or assessed (CCEA, 2014). The requirements include the expectation that pupils will use ICT to "exchange" communication with others. In other words, using 
ICT to link to another school could fall within the framework of what was expected, and even required as part of the curriculum. This sort of alignment between one part of the curriculum, the use of ICT, with another, the need for schools to work together, is one key part of finding a way to sustain such work and make it accessible for all children.

\subsection{Shared Education}

Shared Education, which first emerged as an idea in 2006, was designed to bring about systemic change by underlining the advantages of inter-school collaboration not only in terms of improved community relations but, more generally, in offering wider access to courses at post-primary level and offering a model which could improve staff development and lead to better educational outcomes for pupils (Duffy \& Gallagher 2017; Gallagher, 2016; Hughes \& Loader, 2015; Loader \& Hughes 2017;). In 2015, the Department of Education in Northern Ireland secured external funding to develop the Shared Education Signature Project (SESP) which involves around 380 schools, based on existing cross-community partnerships with a requirement that there be a minimum of 6 face to face sessions per annum for children involved. Following an enquiry by the Education committee in the devolved administration in Northern Ireland, a Shared Education Act (2016) was passed to 'deliver educational benefits to children and young persons', and to promote 'the efficient and effective use of resources', 'equality of opportunity', 'good relations' and 'respect for identity, diversity and community cohesion.' In 2018, the roll-out of shared education to a new cohort of schools (300 schools by 2019) which did not have existing partnerships was introduced through the Collaborative and Shared Education programme (CASE), funded through the European Union. For the first time, it was agreed that as part of the 30 hours contact time which pupils were expected to do, $20 \%$ could be online. (Education Authority, 2018) Around $50 \%$ of the total number of schools in Northern Ireland are now involved in Shared Education, and the Department of Education has made clear its intention to 'mainstream' shared education, noting that 'a two pronged approach which includes face to face contact supplemented by online collaboration is one method to sustain relationships and raise standards' (DE 2018, p.7).

\section{The current research}

The review of the literature above highlights that online contact can enhance intergroup relations (e.g., Harwood et al., 2016; White \& Abu-Rayya, 2012). Moreover, blending online and face-to-face contact has strong support from teachers because it enables long-term engagement between pupils from different schools in a way that is sustainable despite a crowded curriculum (Austin, 2018; Austin et al., 2015; 2017). To date, however, there has been no empirical examination of the impact of blended learning in the context of Shared Education. Yet this is essential to understand whether this approach should play a greater role in Shared Education, and if so, how best to achieve this.

The current research was undertaken in the context of a 2-day face to face training course called Collaborative Learning Online for Shared Education and Reconciliation (CLOSER). The course was shaped by experience drawn from previous professional development on the Dissolving Boundaries Programme and was designed to offer both practical application in relevant communications software and understanding of key theoretical insights in blended learning. Teachers who took part were given guidance and support in the use of a common Virtual Learning platform, called Fronter, a real-time video-conferencing software package called 'Collaborate' and sessions on how these ICT applications could enhance and extend face to face collaborative learning during Shared Education. 
Fronter provides the usual features of a VLE with space for the creation of resources, discussion fora with scope for quizzes and a multi-media library. Collaborate is a 'virtual classroom' where teachers and pupils can interact in real time both visually and orally and where work can be displayed and edited synchronously. Both applications are available to all schools in Northern Ireland at no cost as part of the managed ICT service for schools. The course was taught by an experienced academic, an ICT trainer from C2K and teachers who had already been using blended learning. Teachers undertaking the course were advised on the importance of creating group to group contact between their pupils in line with the contact hypothesis and creating online discussions which had a 'social' element to foster friendships as well as work areas for study of agreed tasks. At the end of the initial 2 days, teachers were asked to deliver a 6 week course with their partner teacher in their schools and return for a final face to face event to present a report on their work. This allowed teachers to reflect on very recent experiences of applying blended learning to their Shared Education classes.

We asked teachers to complete a survey about their experiences, in order to answer 3 key research questions. First, we wanted to examine teachers' prior use of blended learning and the time they allocated to ICT and face to face contact. Further, we wanted to know about the overall impact of their use of blended learning and whether this affected their views for future work. Second, we wished to explore teacher views on the impact of blended learning on their pupils. Finally, we wanted to examine whether a blended approach could support the sustainability of Shared Education, a critical aspect of enabling this work to reach every child.

\subsection{Methodology}

\section{Information about teachers and schools}

58 teachers ( 50 females, 8 males; 36 Catholic, 21 Protestant, 1 with no community affiliation) who were involved in the first phase of Shared Education took part in the research. All participants opted between February 2017 and November 2018 to undertake the module Collaborative Learning Online for Shared Education and Reconciliation (CLOSER). 144 teachers took the module in total, so this represented a return rate of $40.28 \% .51$ taught at primary schools and 3 at post-primary schools (a further 4 participants did not respond to this question). 18 teachers said that their schools were within walking distance of one another, whereas for the remainder public transport was required. $97.00 \%$ of the teachers who attended the training were in school partnerships funded through the Shared Education Signature Project (SESP). It was a condition of involvement in SESP that schools had an existing cross-community partnership and the data showed that these partnerships ranged in duration from 1 year to 26 years $(M=7.86, S D=6.56)$.

\subsection{Procedure}

During the final day, after presenting a report on their application of what they had learned in the context of a Shared Education classroom project, teachers were invited to complete an online anonymous multiple choice questionnaire, using Qualtrics software. The study received ethical approval from the Ulster University's School of Education Ethics Committee.

\subsection{Questionnaire measures}

The questionnaire was developed by the authors for the purpose of the current study. We had 6 teachers who had previously taken part in CLOSER training review the questionnaire and provide 
feedback, in order to ensure the clarity and face validity of the questions. We asked a series of multiple choice questions, using Likert and semantic differential scales, and open ended questions on the following topics: Experience and perceptions of Shared Education, Previous experience of using blended learning software, Details of teachers' blended learning projects, and Perceived value of CLOSER module and blended learning project. Full details of the questionnaire can be found in Appendix 1.

\section{Findings}

Qualtrics data were extracted into SPSS for analysis, and descriptive statistics were undertaken. To reduce the risk of researcher bias since one of the authors was involved in running CLOSER, an academic colleague from another institution who had played no part in the teaching of CLOSER carried out the analysis of the data.

\subsection{Pupils and curricular focus}

Teachers reported that the pupils they had worked with were aged between 4 and 13 years $(M=$ $8.94, S D=1.90)$. All of the teachers reported that their work had been fitted into existing curriculum areas, with several focusing on 'the World around us', 'literacy' and this often included work on internet safety. 2 teachers working in secondary schools linked classes in English and Technology and Design.

\subsection{Research question 2.1 Teachers' prior knowledge and use of ICT}

74.13\% of teachers had little or no knowledge of the VLE Fronter prior to their training and $79.31 \%$ reported a similar lack of knowledge with the synchronous software Collaborate which allows real time video and audio links and a shared whiteboard. In response to a question on whether they had used ICT as part of their previous work on shared education, $70.69 \%$ said it was entirely face to face and $18.97 \%$ said it was mainly face to face. We also wanted to find out if teachers were connecting the ICT work they did in shared education with the requirement for them to assess pupils' work in ICT via the Use of Information Communication Technology (ICT) framework. 16.98\% answered yes to this question, $67.92 \%$ indicated that it 'gave pupils the chance to practice in relevant aspects of the UICT framework', and the remainder said no. This indicates a strong degree of potential alignment between 2 different spheres of school life, namely work in shared education and the assessment of ICT. Given the importance of reliable and accessible ICT to carry out their planned work teachers were asked if they felt that the ICT provision in their schools was adequate. 9.43\% said it was 'adequate' while $54.72 \%$ claimed it was 'somewhat adequate'. The remaining third expressed varying degrees of disappointment with their facilities.

We think it is fair to conclude that this group of teachers were not ICT specialists but could best be described as fairly typical classroom teachers who had an interest in the use of ICT. We cannot say whether they can be regarded as representative of the whole teacher population in Northern Ireland but, given the preponderance of primary school staff in the sample, it would seem likely that the primary teachers were fairly typical of the wider population in primary schools.

\subsection{Research question 2.2 Time spent on Fronter, Collaborate and face to face}


Teachers were asked which of the 3 means of interaction they had spent most time on with their pupils. The most used was the asynchronous VLE, Fronter (45.28\% reported using the most frequently), followed by face to face contact ( $45.10 \%$ reported using most frequently) with relatively little time spent using Collaborate, the real-time video-conferencing software. In terms of explanation for the extensive use of Fronter, $89.80 \%$ thought a very or somewhat important reason was that it was the 'best fit given the goals of their shared education work', while $88.00 \%$ thought a very or somewhat important reason was that it 'fitted in best into a busy day'. Only $18.75 \%$ thought a very or somewhat important reason was that they 'did not feel confident in using ICT'. Teacher comments on the low use of Collaborate were mainly based on not having the right cameras and microphones. In the early stages of CLOSER, there were teething problems with the supply of these items but this was addressed in later courses by providing them for the course and allowing the teachers to take them for immediate use in school. The teachers who were able to make use of Collaborate noted that 'the children were very inquisitive... so we utilised their curiosity to develop and build relationships'.

Teachers were invited to comment more generally on the ways they had used blended learning. One comment which was echoed by others showed how teachers were embedding the new ICT component into their previously planned face to face work to extend and deepen the link;

Initially our Shared Education classes met with an ice-breaker face to face session so that when we progressed to Collaborate the children had some experience of each other and were excited to see themselves and their new friends on screen during follow up collaborate sessions. Fronter fitted in really well at all stages of the programme and was used to prepare for, enhance and build upon face to face contact and collaborate sessions.

Another noted how the tools could be used in different ways and in a different order depending on the pupils and the project;

I used the three methods differently for each project. Year 7 already had face-to-face contact established, so Fronter and Collaborate were used to support the project. Children could share their work completed in respective schools. Year 4 used Fronter to take part in a discussion and share their work. They then used Collaborate to meet and talk about their topic.

Teacher comments also showed that there was no 'magical' order in which to deploy the three ways of making contact. One noted that 'Fronter was used first in order to allow children to get a feel for it and to learn how to exchange during online discussions. The face to face session is happening at the end, to finish off our project together as it slotted in with our topic.' What this shows is that once teachers have the skills to deploy ICT as part of their work in shared education, they use them flexibly to add value to the process of building working relationships.

\section{4 Research Question 2.3: Impact on teachers' views of blended learning}

We asked teachers if their use of ICT on CLOSER had led to improved communication with their own colleagues and with those in the partner schools. $58.49 \%$ said it had done so 'considerably', with a further $39.62 \%$ saying it had 'to some extent'. Teachers were also asked about how they saw the role of blended learning in future planning for Shared Education. The question asked teachers if ICT and 
face to face contact should be regarded as equally important. $56.96 \%$ of teachers 'strongly agreed' with this statement, with a further $31.00 \%$ indicating that they agreed 'somewhat'. In response to a question about whether teachers had found that the CLOSER had been useful for their professional development, $74.10 \%$ said it was 'very useful' with a further $17.21 \%$ saying it was 'quite useful' (the remaining respondents did not answer this question).

\subsection{Research Question 3.1: Contributing elements to pupil knowledge and attitudes}

Teachers were also asked which of the three ways of interacting - Fronter, Collaborate and face to face work - they believed was most important in terms of developing pupils' knowledge of the topics being studied. $79.25 \%$ said that Fronter was the most useful for this with $15.09 \%$ placing face to face as the most important, and $5.66 \%$ suggesting Collaborate was the most important (the remaining respondents did not answer the question). Teachers were also asked which of the three ways of interacting they believe was most important in terms of the development of more positive attitudes towards the children in your partner school. $43.40 \%$ stated that Face to face contact was the most important, $39.62 \%$ stated that Fronter was the most important, and $16.98 \%$ felt Collaborate was of most value.

\subsection{Research Question 3.2: Impact on pupils' experience of shared education}

Table 1 shows the responses of teachers regarding their perceptions of the impact on pupils' experience of shared education. A series of one-way ANOVAs showed no significant difference between teachers from a Catholic or Protestant background in their responses to these questions, suggesting cross-community agreement on the impact of blended learning. The most important change teachers noted in pupils was in terms of the development of friendships ( $M=+1.60, S D=$ .53) indicating between slightly better or much better on average). Teachers noted that, 'more regular access to each other in online forums has meant that children have a chance to chat in a way which is familiar to them' and 'leaving comments for each other on Fronter and then matching the comment to the person during face-to-face activities helped to build on relationships'. Another captured the way that the 3 elements had all contributed to this;

Friendships have been developed from the very beginning of the process... the children were grouped in all the initial face to face meetings, with the groups being different on each occasion. This enabled them to develop friendships with a wider range of pupils from other schools. This was reinforced through using Fronter, where the children found out more about each other and were able to leave comments and interact with other. This in turn was further reinforced through the 'real time' Collaborate session.

Many other comments referred to the 'cementing' or 'reinforcing' of relationships as a result of discovering similar interests through working in a safe online environment and through group to group interaction 'every week'. One comment captured the complementary nature of the tools the teachers had learned;

The different ways to engage children (Fronter/ Collaborate/ F2F) meant that children built up an understanding of their newly established friendships and could remain in contact whilst learning about each other in three important but distinctively different ways. 
The second biggest impact on the children related to getting children ready to work together $(M=$ $+1.41, \mathrm{SD}=.60$ ). We had asked this question since the workplace in Northern Ireland is regarded as the point where people are most likely to encounter those from a different background (Eyben, Morrow, Wilson \& Robinson, 2002). Teachers reported that children had worked well together both online and face to face; one noted that 'group tasks have also encouraged working with others, which has supported children's skills in working with others and communication; these are vital in getting ready to work with others in the future.' The asynchronous nature of Fronter meant that pupils had time to read other pupils' comments and think about how to respond, an approach that suited some pupils better than the immediacy of face to face interaction. And for another teacher, one reason why children worked well together was because they were motivated, they 'looked forward eagerly' to the next interaction. Others simply 'loved sharing and peer assessing work online'.

The area that was seen as next most important was what we called 'normalising relations' between pupils (Mean score $=+1.32, \mathrm{SD}=.67$ ). One teacher wrote that the blended approach fitted very comfortably into the pupils' world because 'regular contact using an online platform is familiar to 10 and 11 year olds in everyday life'. Another reinforced the sense that normalising was taking place because of 'more regular face-to -face contact coupled with greater on-line collaboration... Pupils are no longer out-of-sight out-of-mind. Use of Fronter has let us develop and extend lessons within own schools but pupils are still learning, sharing and responding to each other's work.'

The aspect of Shared Education which teachers saw as coming next in importance was 'respect for difference' (Mean score $=+1.30, \mathrm{SD}=.72$ ). In many of the younger classes, this arose naturally through an online exchange of information about hobbies and interests. One of the teachers noted that 'the children were able to ask questions about each other's hobbies such as Gaelic and football or Irish dancing or Scottish dancing'. Another commented that 'pupils applied online safety protocols which naturally led to respect for difference. Pupils showed respect even in terms of the names they weren't familiar with. Comments made on Fronter demonstrated respect'. Collaborate enables realtime interaction, including the sharing of music; for one teacher this meant 'hearing songs in Irish near St Patrick's day gave children more of an insight into a different culture'.

Although improvement in academic performance was not seen as a high priority by the majority of teachers, they did on average perceive there to be a slightly improvement in children's performance $(\mathrm{M}=+.77, \mathrm{SD}=.67)$. Comments showed that the presence of an audience for pupils' work had been motivational. One teacher noted that 'children are more engaged with completing tasks online. They have improved ICT skills, they are more aware of their spelling and grammar, they self-edit and they have a wider audience for peer assessment.' Another echoed these perceptions, underlining the power of the communicative side of ICT;

Children were enthused by the use of technology to engage with their new friends. This enthusiasm meant that children engaged more fully in art and literacy/ ICT activities that they shared online and in Fronter room with their buddies.

And, according to another teacher, this meant that in addition to improved attitudes to work, pupils were also developing skills in both ICT and literacy, helping teacher meet targets and raising standards. The link with the pupils in the other school meant that 'pupils are seeing themselves how their potential can be raised.' 
A number of teachers referred specifically to the way that online discussions in the pupil forum had benefitted pupils with learning difficulties. 'It was fantastic to see 2 particular children in my class with learning difficulties writing their views in forums without hesitation, they didn't get hung up on spelling and felt confident to expand their thoughts'.

The way that the technology spurred reluctant learners was captured in detail by a teacher working in a secondary school who noted how both Collaborate and Fronter were making a real difference to her class, especially to the boys. This project involved pupils in an English class working in partnership with a class taking technology and design (T\&D); the English pupils were acting as potential commissioners of a new product, a new design of hairbrush, which the T \& D pupils were to design.

Literacy focus definitely improved academic performance. Notable difference in talking and listening skills - pupils put more effort into presenting via Collaborate as they had a real audience they wanted to impress, whereas presenting to your own class can become monotonous as they are with each other all the time meaning they don't put the same effort into it. Boys in my class tend to switch off when it comes to Literacy although through the activities planned, they didn't realise they were doing Literacy so it was certainly motivational meaning the quality of work was improved. Furthermore, it can be hard to motivate pupils to spell and punctuate correctly in their classwork books but were more eager to do this properly in Fronter discussion because it was online and linked into their interests as they use similar forums at home. Also, proof reading and editing is often an issue as pupils simply cannot be bothered, whereas on the Fronter discussions it was easier to proof read and edit their comments as they were short and also meant they could spend longer on the computer if they took time to proof and edit it!'

The two final areas where teachers were asked to comment on whether there had been any change were 'reconciliation' ( $M=+0.64, S D=.68)$ and 'handling controversial issues' $(M=+0.45, S D=.67)$. These were regarded as having been least affected by their experiences in Shared Education. In terms of reconciliation, one teacher noted that the young age of the children and the specific location of the schools were possible factors;

I'm not sure how much the children appreciated that children from other schools may have been of a different religious background to themselves. They just saw each other as children. Therefore I don't know how much this process promoted reconciliation in our process - this may differ according to what area each of the schools is in geographically throughout N. Ireland.

Another pointed to the relatively short time the schools had been working together to explain why reconciliation was perhaps too big a goal. 'Perhaps too short for notable change in this area this is the first time these particular classes have took part in Shared Education lessons. Can see how reconciliation would result over a long term approach of shared education.' What these teachers felt they could do was, as one put it, to create the conditions in which 'the children were able to appreciate differences between their communities but also able to learn and find a common ground together.' 
Finally, in terms of 'handling controversial issues' it was clear that teachers avoided these, felt this was inappropriate for the age of the children they were working with but there was a recognition that 'this could be approached if pupils have been involved in Shared Education projects throughout their time in primary school'.

\section{Discussion}

The current study is the first to examine teachers' experience of applying blended learning in the context of their Shared Education partnership, and their perceptions of the impact that blended learning had. Given that up to $20 \%$ of Shared Education classes can now be undertaken online, it is crucial to understand more about the role that blending online contact with face-to-face experiences in the class can have in realising the goals of Shared Education. Our findings reveal 4 issues which deserve to be highlighted.

5.1 First, it is clear that professional learning courses like CLOSER are essential for teachers to be able to realise the potential of blended learning, especially where, as in this case, specific sessions were set aside for teachers in linked partnerships to reflect on what they believed to be the core goals for Shared Education We recommend that stronger emphasis is also put on blended learning during initial teacher training, as well as in continued professional development courses, to ensure that it is embedded into the system so that its positive impact can be maximised.

5.2 Second, in terms of the specific software that enables interaction between schools, the teachers in this sample, predominantly from the primary sector, found that the VLE Fronter was suitable for asynchronous contact between pupils in this age range. This is an important finding since all schools in Northern Ireland have access to Fronter as part of the managed service provided by $\mathrm{C} 2 \mathrm{~K}$. Fronter does not require teachers who are specialists in educational technology; the teachers in our sample were non-specialists who learned the essentials in 2 days. This suggests that rolling out Shared Education to all schools within Northern Ireland with a blended learning approach would be realistic. Further investment and support is needed to get the full benefits of the real-time Collaborate software. As part of the 'refreshment' of software provided for through the $\mathrm{C} 2 \mathrm{~K}$ contract, there is a case for investing in new communications software that is both secure but also capable of connecting schools within Northern Ireland and elsewhere.

5.3 Third, the data indicates that blended learning through Shared Education has been very successful at delivering a range of outcomes for pupils in terms of attitudes, knowledge and skills, especially around 'friendship', 'preparing children to work together', 'normalising relations' and 'respect for difference'. Teachers provided valuable narratives on how blended learning helped to promote these outcomes. An especially important outcome to arise was around the sustenance of friendships. It seems that blended learning allowed cross-community relationships to develop in a smoother, less disjointed and therefore sustained manner than face to face contact alone, which is inevitably interrupted when children are attending different schools. In particular, the asynchronous tool Fronter allowed children from the two schools to reciprocally share information about themselves with one another between face to face classes. This self-disclosure has been found to be critical in the development of cross-group friendships which promote more positive cross-community perceptions among pupils in Northern Ireland (Turner et al., 2013; see 
also Turner et al., 2007). In light of this, it makes sense that teachers felt that Shared Education had helped to normalise cross-community relations and enhanced respect for difference.

Teachers also felt that children felt better prepared for working together following blended learning because they were learning how to communicate with one another through group activities. Turner \& Cameron (2016) recently pointed out the huge potential value of ensuring that children develop confidence in engaging with people from different backgrounds as they leave school and engage with the wider community and workplace

Interestingly, blended learning did not have the same level of impact in terms of 'reconciliation' and 'handling controversial issues'. Children's and teachers' understanding of these issues must be explored in more depth in future research, but this might reflect the relatively young age of the children being taught and the complexity of these concepts. This highlights the importance of taking into account the age and developmental stage of the children being taught when working towards achieving the goals of Shared Education (e.g., see Turner \& Cameron, 2016). One might also argue that Shared Education is well established in many of these schools, and thus relations are relatively positive and there is a feeling that there is nothing to discuss. However, the lack of discussion around reconciliation and controversial issues is, we believe, problematic. While promotional materials for Shared Education highlight the direct focus on talking about issues of identity and reconciliation, there are in fact no clear guidelines on how these issues should be discussed. In interviews with 60 children involved in Shared Education, Loader and Hughes (2017) found that more than half of pupils spoke of feeling awkward in relation to addressing differences and actively avoided those subjects. Moreover, teachers reported feeling awkward leading these discussions. The lack of discussion also reflects a wider cultural issue in Northern Ireland around discussion of contentious issues in mixed settings 'deemed socially gauche' (Donnelly, 2004, p. 12). There is also evidence that in some cases school leadership discourages discussion of difference (McGlynn, 2008). It is important to deal with these issues because failure to discuss them can heighten intergroup bias (e.g., Pahlke, Bigler, \& Suizzo, 2012). Moreover, when conversations around cross-community issues are avoided, pleasant contact leaves institutional, social and political structures that perpetuate inequality and conflict intact (Dixon, Durheim, Kerr, \& Thomae, 2013; Hughes \& Loader, 2015).

5.4 Fourth, it would appear that mainstreaming Shared Education, extending it to every child in every school in Northern Ireland, needs to make the fullest use of the ICT infrastructure to provide a cost-effective way to extend face to face contact. This is a marked departure from the model of shared education which has relied exclusively on face to face contact as the primary engine for pupil interaction. Prior to the introduction of the CLOSER module is 2017, there was no recognition that blended learning had any role to play in shared education.

5.5 Finally, these findings also highlight the potential benefits of blended learning in other jurisdictions where shared education-type programmes are used to increase interaction across segregated education systems, for example Israel (Shonfeld, Hoter \& Ganayem, 2013), BosniaHerzevogina (Tolomelli, 2015), Macedonia and Albania (Bakiu, Dimitrova, \& Brava, 2016), and Croatia (Čorkalo Biruški \& Ajduković, 2016) 


\section{Limitations and Further Research}

6.1 It is important to acknowledge limitations of the current research. First, the survey had a small sample but the proportion of primary and post-primary teachers was broadly reflective of the number of schools in Northern Ireland. It is also notable that participants had a wide geographical spread, included teachers from both recently established and long-term Shared Education partnerships, and represented both communities. Nonetheless it would be worthwhile to examine on a larger scale teachers' experiences with, and perceptions of, blended learning in the context of Shared Education. Larger samples of primary and secondary school teachers would also enable a comparison between the two, given that the developmental stage of children may impact on the effectiveness of contact-based interventions (see Turner \& Cameron, 2016, for a discussion).

6.2 Second, we did not use a validated scale for this study, instead developing our own items. This is because there were specific questions that we wanted to address around what we know to be the aims of Shared Education, and how ICT and blended contact were used. In order to encourage teachers to complete the questionnaire in their busy schedule, we also used single item measures to keep the questionnaire brief. In order to facilitate future research on the efficacy of blended contact, it would be worthwhile to develop validated multi-item scales to capture the impact of blended contact.

6.3 Third, although our findings highlight the value of blended contact, we unfortunately did not have a large enough sample to compare different styles of implementation of blended contact (for example, online followed by face-to-face versus face-to-face followed by online). An important avenue of future research will be to identify how exactly blended contact might be used for maximal impact.

6.4 Fourth, teachers' perceptions of the effectiveness of Shared Education may differ from those of the students. An important goal of future research will be to examine how blended learning as part of Shared Education impacts on children, particularly in terms of areas that emerged here as particularly important, for example the development of new cross-community friendships.

\section{Conclusion.}

Despite these limitations, these findings suggest that training for blended learning, improved ICT resources in schools, and in turn, implementation of blended learning in Shared Education partnerships, should be rolled out more broadly in Northern Ireland. We believe this will have the potential to maximise the potential benefits of Shared Education, particularly in terms of crosscommunity friendships, preparing children to work with those from different backgrounds for themselves, normalising cross-community relations, and enhancing respect for difference. Although Northern Ireland has a specific set of issues arising from a unique set of political and historical circumstances, the role of schools in promoting community cohesion is now a global concern; in that sense we believe the findings have significance in other parts of the world. 
We acknowledge the very helpful comments on early drafts of this paper provided by Professor Bill Hunter, Dr Elizabeth Worden, Professor Kader Parahoo and Professor Linda Clarke

Funding

This research did not receive any specific grant from funding agencies in the public, commercial, or not-for-profit sectors

Table 1: Perceived impact of blended learning project on the goals of Shared Education

\begin{tabular}{|l|l|l|l|l|}
\hline & $\begin{array}{l}\text { Catholics } \\
\text { M (SD) }\end{array}$ & $\begin{array}{l}\text { Protestants } \\
\text { M (SD) }\end{array}$ & $F$ & $p$ \\
\hline Sharing resources & $0.94(.79)$ & $0.95(.97)$ & .59 & .56 \\
\hline Normalising relations & $1.39(.66)$ & $1.21(.71)$ & .55 & .58 \\
\hline Getting children ready to work together & $1.45(.67)$ & $1.37(.50)$ & .36 & .70 \\
\hline Improving academic performance & $0.76(.66)$ & $0.84(.76)$ & .71 & .50 \\
\hline Developing friendships & $1.67(.48)$ & $1.53(.61)$ & 1.08 & .34 \\
\hline Developing respect for difference & $1.33(.78)$ & $1.21(.63)$ & .64 & .53 \\
\hline Promoting reconciliation & $0.64(.65)$ & $0.63(.76)$ & .14 & .87 \\
\hline Dealing with controversial topics & $0.48(.67)$ & $0.42(.69)$ & .28 & .76 \\
\hline
\end{tabular}




\section{Appendix 1: Study Questionnaire}

Experience and perceptions of Shared Education. Participants indicated the length of the Shared Education partnership at their school, and distance between the partnered schools. They then indicated importance ( 1 = not at all important, 5 = very important): of the following possible aims shared education: Sharing resources/facilities /staff development; Normalising relations between young people; Getting children ready to work together; Improving academic performance; Developing friendships; Developing respect for difference; Reconciliation; Dealing with controversial topics.

Previous experience of using blended learning software. Participants were asked 'Prior to the CLOSER course, how proficient were you in the use of Fronter?' and 'Prior to the CLOSER course, how proficient were you in the use of Collaborate?' ( $1=$ not at all, $4=$ very much), and 'Prior to the CLOSER course, to what degree was your work in shared education based on face to face contact?' ( 1 = entirely face to face contact, $5=$ entirely online).

Details of teachers' blended learning projects. Teachers completed open ended questions regarding the curricular focus of their project, and what any face to face sessions involved. They were then asked which method of contact they used the most (Fronter, Collaborate, Face to face), and why. They were next asked to rank the order in which they used face to face contact, Collaborate, and Fronter during their project, before indicating their agreement with each of the following reasons for this order 'I felt most confident in using Fronter', I felt most confident in using Collaborate', 'I felt most confident using face to face contact', 'We did not have a face to face meeting planned', Collaborate was used at the start to make the link feel 'real'" ( 1 = strongly disagree, 5 = strongly agree). Teachers then indicated which of the 3 ways of interacting was the most important in terms of (a) developing knowledge and (b) developing more positive attitudes towards children in the partner school. Participants were also asked whether ICT resources in their school were adequate (1 = strongly agree, 4 = strongly disagree), and to provide details of any difficulties faced with ICT. Moreover, teachers were asked 'Did you use the project as a way of developing and assessing ICT skills related to the CCEA framework for UICT? Please select one of the comments below': 'Yes, they were part of the planning', Pupils used ICT in ways that gave them practice in relevant aspects of the UICT framework, and 'No, there was no link between the ICT work for the shared education project and UICT'.

Perceived value of CLOSER module and blended learning project. Teachers were asked how useful they felt CLOSER had been for their professional development ( $1=$ very useful, $4=$ of little or no use), and whether future planning for Shared Education for ICT ( $1=$ strongly agree, $4=$ strongly disagree). Next, we assessed teachers' perceptions of change in their pupils on the following areas of the project: 'Sharing resources and facilities', 'Normalising relations between young people from different community backgrounds', 'Getting children ready to work together', 'Academic performance', 'Developing friendships', 'Developing respect for difference', 'Reconciliation', and 'Dealing with controversial topics' (for each of these items, $-2=$ things got much worse), -1 things got a bit worse, $0=$ no change,$+1=$ things got a bit better, or +2 things got a lot better). Teachers could also provide a rationale for each response. 


\section{References}

Abbott, N., \& Cameron, L. (2014). What makes a young assertive bystander? The effect of intergroup contact, empathy, cultural openness, and ingroup bias on assertive bystander intervention intentions. Journal of Social Issues, 70, 167-182.

Abrams, D. (2010). Processes of prejudice: Theory, evidence and intervention. Equality and Human Rights Commission Research Report 56 London: EHRC. http://www.equalityhumanrights.com/sites/default/files/documents/research/56_processes_ of_prejudice.pdf Accessed 18 May 2015

Allport, G. W. (1954). The Nature of Prejudice, Reading, MA: Addison Wesley.

Archik, K. (2018). Northern Ireland: Current Issues and Ongoing Challenges in the Peace Process. https://fas.org/sgp/crs/row/RS21333.pdf. Accessed on 27 May 2018

Assistant Chief Inspector (2012). The Education and Training Inspectorate, Northern Ireland, The Dissolving Boundaries Programme http://www.etini.gov.uk/index/surveysevaluations/surveys-evaluations-post-primary/surveys-evaluations-post-primary-2012/jointevaluation-report-dissolving-boundaries-programme-2010-2011.htm

Austin.R and Hunter.W, (2013) 'Whatever you say, say nothing: Student perceptions of online learning and community in Northern Ireland', Irish Educational Studies

Austin, R., Rickard A., \& Reilly J. (2017) Face-to face contact in blended learning for intercultural education: the role of teachers. Irish Educational Studies, 36, 323-340

Austin, R., \& Hunter, W. (2012). Stirring Political Pots: ICT, Denominational Reform, Northern Ireland, Newfoundland and Labrador. In G. Galway. \& D. Dibbon (Eds.) Educational reform: From rhetoric to reality. London: The Althouse Press. 253-274.

Austin, R. (2018) Blended Contact for Community Cohesion in Northern Ireland and the Republic of Ireland. In M. Shonfeld \& D. Gibson (Eds). Collaborative Learning in a Global World.

Austin, R., Hunter, W., \& Hollywood, L. (2015). Supporting community cohesion through ICT: The epartners programme in Northern Ireland, Computers in Human Behaviour, 52, 508-514

Austin, R., \& Hunter, W. (2013). Online Learning and Community Cohesion: Linking Schools, New York and London, Routledge ISBN: 9780415510288

Austin, R., \& Anderson. J. (2008). E-schooling; global messages from a small island. London: Routledge

Bakiu, B., Dimitrova, M. \& Brava, A. (2016). How to Achieve A Truly Integrated Education in the Republic of Macedonia? Dialogues For Vision: How to Achieve Integrated Education in the Republic of Macedonia

[http://www.epi.org.mk/docs/[D4V]How\%20to\%20Achieve\%20Integrated\%20Education\%20in \%20the\%20Re public\%20of\%20Macedonia.pdf

Brown, R., Baysu, G., Cameron, L., Nigbur, D., Rutland, A., Watters, C., Hossain, R., LeTouze, D., \& Landau, A. (2013). Acculturation attitudes and social adjustment in British South Asian children: a longitudinal study. Personality and Social Psychology Bulletin, 39, 1656-1667.

Bonnell, J., Copestake, P., Kerr, D., Passy, R., Reed, C., Salter, R., Sarwar, S. \& Sheikh, S. (2011). Teaching Approaches That Help to Build Resilience to Extremism among Young People (DFE Research Report 119). London: DFE. Available at https://www.education.gov.uk/publications/standard/publicationDetail/Page1/DFE-RR119 p.97

Čorkalo Biruški, D. \& Ajduković, D. (2016). Young adults' perspective of social reconstruction in three post-war communities in Croatia and Bosnia-Herzegovina. In M. Fischer \& O. Simić (Eds.), Transitional justice and reconciliation. Lessons from the Balkans (pp. 169-192) London: Routledge.

Curriculum Council for Examinations and Assessment (CCEA). Personal Development and Mutual Understanding. Available at 
http://www.nicurriculum.org.uk/curriculum_microsite/pdmu/living_learning_together/home. asp

Department of Education, Northern Ireland (2018). Mainstreaming of shared education-long term proposals. Consultation paper.

Department of Education for Northern Ireland (2015). Sharing Works: A Policy for Shared Education. Available at https://www.educationni.gov.uk/sites/default/files/publications/de/Sharing\%20Works\%20A\% 20Policy\%20for\%20Shared\%20Education\%20Sept\%202015.PDF.

Dixon, J., Durrheim, K., Kerr, P. and Thomae, M. (2013). 'What's so funny 'bout peace, love and understanding?' Further reflections on the limits of prejudice reduction as a model of social change, Journal of Social and Political Psychology, 1, 239-252. doi:10.5964/jspp.v1i1.234.

Donnelly, C. (2004). What price harmony? Teachers' methods of delivering an ethos of tolerance and respect for diversity in an integrated school in Northern Ireland, Educational Research, 46, 3-16. doi:10.1080/0013188042000178782.

Dovidio, J. F., \& Gaertner, S. L. (2000). Aversive racism and selection decisions; 1989-1999. Psychological Science, 11, 315-319.

Duffy. G., \& Gallagher, T. (2017). Shared Education in contested spaces: How collaborative networks improve communities and schools, Journal of Educational Change, 18, 107-134

Education Authority (2018), Business Case-Online Collaboration for CASE. Internal memo to Special EU Programmes Body

Education and Training Inspectorate (2012), 'Joint Evaluation Report Department of Education and Skills Inspectorate - Republic of Ireland Education and Training Inspectorate - Northern Ireland Dissolving Boundaries Programme 2010/2011', accessed at https://www.etini.gov.uk/publications/joint-evaluation-report-department-education-andskills-inspectorate-republic-ireland, Accessed 15 July 2019

Eyben, K., Morrow, D., Wilson, D., \& Robinson, B. (2002). The equity, diversity and interdependence framework: A framework for organisational learning and development. University of Ulster.

Gallagher, T. ( 2016) Shared education in Northern Ireland: school collaboration in divided societies. Oxford Review of Education, 42, 362-375.

Galway, G., \& Dibbon, D. (2012) Educational reform: From rhetoric to reality. London: The Althouse Press.

Harwood, J., Hewstone, M., Amichai-Hamburger, \& Tausch, N. (2016). Intergroup contact: An integration of social psychological and communication perspectives, Annals of the International Communication Association, 36, 55-102

Hasler, B. S., \& Amichai-Hamburger, Y. (2013). Online intergroup contact. In Y. Amichai-Hamburger (Ed.), The social net. Human behavior in cyberspace (2nd ed.), 220-252. New York: Oxford University Press.

Hughes, J. \& Loader, R. (2015). 'Plugging the gap': shared education and the promotion of community relations through schools in Northern Ireland. British Educational Research Journal, 41, 1142-1155

Kerr, D. Keating. A, Poet.H, Spielhofer.T, Lopes.J \& Mundy.E (2011). Evaluation of the Schools Linking Network: Final report. Ref: DFE-RR090

http://eprints.ioe.ac.uk/17567/1/SNOZ_final_report_published.PDF (accessed 30/05/2018)

Loader, R. \& Hughes, J. (2017). Joining together or pushing apart? Building relationship and exploring difference through shared education in Northern Ireland. Cambridge Journal of Education, 47, 117-134

McGlynn, C. (2008). Leading integrated schools: A study of the multicultural perspectives of Northern Irish principals. Journal of Peace Education, 5, 3-16.

Muldoon, O., Trew, K., Todd, J., Rougier, N., \& McLaughlin, K. (2007). Religious and National Identity after the Belfast Good Friday Agreement. Political Psychology, 28, 89-103 
Niens, U., Kerr, K. \& Connolly, P. (2013). Evaluation of the effectiveness of the "promoting reconciliation through a shared curriculum experience" programme. Belfast: Centre for Effective Education, Queen's University Belfast

Northern Ireland Statistics and Research Agency (2011), Key Statistics for Northern Ireland. Census 2011.

O'Connor, U., Beattie, K. \& Niens, U. (2008). An evaluation of the introduction of local and global citizenship to the Northern Ireland curriculum. Council for the Curriculum, Examinations and Assessment. UNESCO Centre, University of Ulster.

O'Connor, U., Hartop.H \& McCully.A (2002). A review of the schools community relations programme. Bangor (Northern Ireland): Department of Education.

Pahlke, E., Bigler, R. S., \& Suizzo, M. A. (2012). Relations between colorblind socialization and children's racial bias: evidence from European American mothers and their preschool children. Child Development, 83, 1164-1179.

Pettigrew, T. F., \& Tropp, L. R. (2006). A meta-analytic test of intergroup contact theory. Journal of Personality and Social Psychology, 90, 751-783.

Police Service for Northern Ireland (2018). Incidents and Crimes with a Hate Motivation recorded by the Police in Northern Ireland. Quarterly Update, 31 March 2018. Accessed at

https://www.psni.police.uk/globalassets/inside-the-psni/our-statistics/hate-motivationstatistics/2017-18/quarterly-hate-motivations-bulletin-period-ending-mar18.pdf

Rickard, A., \& Austin, R. (2017). Assessing Impact of ICT Intercultural Work. The Dissolving Boundaries Program, in Tomei, L. (Ed)., Exploring the New Era of Technology-Infused Education. Hershey, PA: IGI Global. doi:10.4018/978-1-5225-1709-2, pp 102-120

Taylor. R. (2006). The Belfast Agreement and the Politics of Consociationalism: A Critique. Political Quarterly, 77, 217-226

Shonfeld. M, Hoter, E., \& Ganayem, A. (2013). Israel: Connecting Cultures in Conflict. In R. Austin \& W. Hunter (Eds.), Online Learning and Community Cohesion. London: Routledge (pp 41-59).

Tolomelli, A., (2015) Two schools under one roof.

The role of education in the reconciliation process in Bosnia and Herzegovina. Journal of Theories and Research in Education, 10.

Trew, K. (1989). Evaluating the impact of contact schemes for Catholic and Protestant children. In J. Harbison, J. (Ed)., Growing up in Northern Ireland. Belfast: Stranmillis College.

Turner, R. N. \& Cameron, L. (2016). Confidence in contact: A new perspective on promoting crossgroup friendship among children and adolescents. Social Issues and Policy Review, 10, 212246.

Turner, R. N., Hewstone, M., \& Voci, A. (2007). Reducing explicit and implicit prejudice via direct and extended contact: The mediating role of self-disclosure and intergroup anxiety. Journal of Personality and Social Psychology, 93, 369-388

Turner, R. N., Tam, T., Hewstone, M., Kenworthy, J., \& Cairns, E. (2013). Contact between Catholic and Protestant schoolchildren in Northern Ireland. Journal of Applied Social Psychology, 43, 216-228.

West, K. \& Turner, R. N. (2014). Using extended contact to improve physiological responses and behavior toward people with schizophrenia. Journal of Experimental Social Psychology, 50, 5764.

West, K., Turner, R. N., \& Levita, L. (2015). Applying imagined contact to improve physiological responses in anticipation of intergroup interactions and the perceived quality of these interactions. Journal of Applied Social Psychology, 45, 425-436.

White, F. A., \& Abu-Rayya, H. M. (2012). A dual identity-electronic contact (DIEC) experiment promoting short-and long-term intergroup harmony. Journal of Experimental Social Psychology, 48, 597-608.

White, F. A., Turner, R. N., Verrelli, S., Harvey, L., J., \& Hanna, J. R. (2018). Improving intergroup relations between Catholics and Protestants in Northern Ireland via E- contact. European 
Journal of Social Psychology, doi: 10.1002/ejsp.2515 